\title{
Nomenclature of Bacteria with Special Reference to the Order Actinomycetales $^{1}$
}

\author{
THOMAS G. PRIDHAM
}

Northern Regional Research Laboratory, ${ }^{2}$ Peoria, Illinois 61604

\begin{abstract}
The number of names for streptomycetes that is in the scientific literature now is exceeded only by those for organisms placed in the genus Bacillus Cohn 1872. The genus Streptomyces Waksman and Henrici 1943 may well rank in first place if names in the patent and quasiscientific literature are included. The overwhelming number of names and the lack of a precise definition of a particular species or subspecies, of type or neotype strains, and of certain essential details have brought about problems in assessing the status of many names. The major problems encountered in a 2-year study are discussed, and a simple format is suggested, use of which may help to clarify future nomenclature.
\end{abstract}

Twelve years ago, I presented (29) before the First Latin-American Congress for Microbiology held at Mexico, D.F., some suggestions on establishing a logical order in streptomycete classification.

(i) Compilation and evaluation of available literature on nomenclature and characterization of streptomycetes.

(ii) Decision on the proper code of nomenclature to follow and on a common language to describe new taxa.

(iii) Agreement on generic names to be used.

(iv) Check of type strains and their recharacterization by contemporary methods.

(v) Assignment of numbers to each important named or unnamed strain reported in the literature.

(vi) Agreement on designation of a minimum set of substrata and tests for characterization of strains.

(vii) Determination of ranges of variation within particular taxa, if possible.

(viii) Provision for adequate preservation of cultures of type strains.

In the ensuing years, considerable advancement has been made on some of these suggestions. Actinomycetologists have agreed (1) on using the International Code of Nomencla-

1 Presented at a round table on Nomenclature of Actinomycetales at the 10th International Congress for Microbiology, Mexico, D.F., 9-15 August 1970.

2 This is a laboratory of the Northern Marketing and Nutrition Research Division, Agricultural Research Service, U.S. Department of Agriculture. ture of Bacteria (20); type strains, where these can be located and obtained, are being assembled and recharacterized (35-38) through the International Streptomyces Project, and a minumum set of substrata and tests have been recommended for description of Actinomycetales in patents $(11,12)$.

One item upon which insufficient attention has been focused is nomenclature. For the past several years I have been engaged in a practical application of the International Code of Nomenclature of Bacteria (hereinafter referred to as the Code). My results have been informative, yet disappointing, frustrating, and mentally exhausting. My experience is an indictment against departments of bacteriology, microbiology, and biology the world over. Although I speak primarily to actinomycetologists, unquestionably my remarks apply to other subdisciplines within microbiology. Too many of us either do not know about the Code, do not understand it, or simply choose to ignore it. On the other hand, those concerned with the development of the Code may not have fully realized the impact of applied microbiology or of the teamwork approach in solving microbiological problems. Applied microbiology and the research team present many new problems to the nomenclature of microorganisms, particularly the Actinomycetales and other taxa of industrial-economic interest. I daresay that a majority of the new taxa which confront us now have come from applied microbiology. Therefore its stake in nomencla- 
ture is high. I am particularly concerned because classification and nomenclature seem to move along separate pathways. Taxonomists should apply the correct names to their taxa. Hence, the relationship between the two disciplines should be closer.

As shown in Table 1, the number of names of streptomycetes in the scientific literature now is exceeded only by the number of names of organisms placed in the genera Bacillus Cohn 1872 and Bacterium Ehrenberg. (The name of the latter genus has been placed on the list of rejected names.)

The genus Streptomyces Waksman and Henrici 1943, when combined with the genus Actinomyces Harz 1877, most of which are streptomycetes or streptoverticillia anyway, may well rank in first place as far as number of named species and subspecies is concerned if those in the patent and quasiscientific literature are included. The overwhelming number of names, lack of a precise definition of a species or subspecies, lack of type or neotype strains, and lack of essential details associated with particular names have brought about questions in assessing the status of many names.

My task was a frustrating one complicated initially by translation, the Actinomyces versus Streptomyces, and patent problems. I will discuss some of these and present a simple format that may help to alleviate the situation in the future. Unless more attention is paid to the Code, I predict continuing confusion and much busy work in the years to come, especially if one considers the multitude of new names that might be proposed through application of a typological-nominalistic kind of species concept. The information I have gathered suggests that literal interpretation of the Code would result in a rather short list of names of organisms belonging to the order Actinomycetales that are scientifically correct.
Only by taking certain liberties can one arrive at any reasonably accurate contemporary picture of the Order as it is known from a taxonomic viewpoint. The taxonomic information is there, but there are problems associated with communicating this information through nomenclature.

Perhaps we have lost sight of the principal reason for naming a microorganism, i.e., to facilitate communication. In virtually every microbiological operation one ultimate question that arises is, "What is the name of the organism?" The accuracy of this determination eventually reflects the state of the discipline and its progress. Despite the fundamental discoveries that have come out of pure taxonomy and despite the excellent chemical work resulting from studies of secondary metabolites, our means of communicating in terms of the microorganisms involved is in a sad state because of failures to follow the Code. Or, perhaps from another viewpoint, the Code may be too involved and restrictive. Because of its complex nature, it may present too many obstacles for practical application. Only in Principle 8 of the Code do I find reference to an explanation of why microorganisms are named: "... to supply a means of referring to taxa." Savory (34) gives a fuller discussion in his interesting little book on nomenclature. Of course, to aid communication any kind of system or supplement would suffice, provided it is acceptable. Suggestions toward this end have been made $(13,39)$, but the binary system supplemented with strain designations still appears to be the most acceptable, at least to me, for the Actinomycetales.

Scientists require that a name be correct according to certain rules. However, because of the impact of applied microbiology, we are in a position where scientific law and the much older juridicial law (10) are opposed in certain

TABLE 1. Number of pages in Index Bergeyana and its three supplements containing entries for some representative genera

\begin{tabular}{|c|c|c|c|c|c|}
\hline \multirow[b]{2}{*}{ Genus } & \multicolumn{5}{|c|}{ No. of pages } \\
\hline & $\mathrm{IB}^{a}$ & IB-1 & IB-2 & IB-3 & Total \\
\hline Bacillus .. & $188-1 / 2$ & 2 & $11-1 / 2$ & $1-1 / 4$ & $203-1 / 4$ \\
\hline Bacterium (illegal) $\ldots \ldots \ldots \ldots \ldots \ldots$ & 109 & $1-1 / 2$ & $12-1 / 2$ & $3 / 4$ & $123-3 / 4$ \\
\hline Actinomyces-Streptomyces . . . . . . . & 77 & $2-1 / 2$ & 8 & $2-1 / 2$ & 90 \\
\hline Salmonella $\ldots \ldots \ldots \ldots \ldots \ldots$ & 81 & 0 & 0 & 0 & 81 \\
\hline Pseudomonas & $37-3 / 4$ & $2-1 / 4$ & 0 & 0 & 40 \\
\hline Micrococcus . & 36 & $1 / 2$ & 0 & 0 & $36-1 / 2$ \\
\hline
\end{tabular}

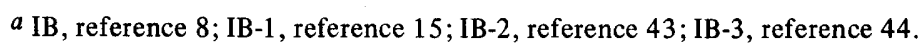


areas, e.g., Rule 11 of the Code, wherein names of bacteria published in patents are not recognized as valid.

Of the three initial broad problems I encountered, that of translation, though difficult, is perhaps the simplest to solve. Lack of adequate services or capabilities for translating a variety of languages leads to a considerable lag or breach in communication simply because too few people are adept in all foreign languages, taxonomic papers may not have high priority for translation services, and translations are expensive. I am beginning to look with jaundiced eye on the time, effort, and expense of obtaining translations when much of the information turns out to be of little or no real value. Only through much perseverance and the help of many colleagues was I able to get reasonable translations of much of the material needed to evaluate adequately the taxonomy and nomenclature involved in my study. During this work I pondered with some nostalgia on an older requirement for descriptions of microorganisms in Latin, a language most of us might bungle through with some ease. Lack of a universally acceptable language will continue to hamper our efforts, and increased international communication will amplify the problem.

The Actinomyces-Streptomyces problem has been and is particularly frustrating because of the requirement of the Code with respect to proposal of new combinations [Rule 12c (3)]. Lessel's (24) remarks about this point are worth noting. As it now stands, one must give a very flexible interpretation of the literature where many new combinations are implied but not definitely proposed, as Rule $12 \mathrm{c}$ (3) requires. Unless we resolve the ActinomycesStreptomyces controversy, we can look forward to a double nomenclature for these organisms and much unnecessary documentation of that nomenclature. So far as I am concerned, the genera Actinomyces and Streptomyces are different, and many taxa placed in the genus Actinomyces are, in fact, streptomycetes and streptoverticillia (30).

Another aspect of the problem of proposing new names and combinations concerns subspecies. Occasionally an author will propose a subspecific name without the species name ever having been independently proposed. For example, Leimgruber et al. (23) proposed the name Streptomyces refuineus var. thermotolerans without proposal of the species name Streptomyces refuineus, which to my knowledge has not been previously published elsewhere. There certainly is a need for taxonomists to consider the impact of their taxonomic reports on nomenclature. This consequence can be fully appreciated only through study of the Code and implementation of its "Principles, Rules, and Recommendations." Resolving taxonomic problems also will ultimately clarify some of the nomenclatural problems.

The third major problem I encountered revolves around Rule 11 of the Code and concerns names of organisms published in patents. I am fearful that this Rule may have placed nomenclatural specialists in a position worse than before the Rule was promulgated. I still am not certain as to the reason(s) for its proposal. In the review of this manuscript, three reviewers offered the following as their ideas of the reasons for promulgation of Rule 11: The patent literature is not sufficiently available unless one knows of its existence, and published patents are not taken automatically by even large institutions; they are not edited by microbiologists; new names are in most cases difficult to find in the patent literature, the titles ordinarily do not contain the names, the names are not indexed, and in many cases the titles do not even give a clue that the patent contains a new name; it is impossible to gain access to the culture upon which the patent description is based. In my view, the taxonomy contained in most patents has as much validity as in any other kind of printed matter. The same questions would arise in interpreting patent taxonomy as in scientific publications. Patents hold a better psoition than most scientific printed matter from the standpoint of date of publication, the date being precisely specified to the month and day, whereas publication dates for journals, etc., are not always so precisely specified. Rule 12 a further confuses the issue by allowing the date of patent issuance to take priority, if and when the patent name is validated in a later-appearing scientific publication.

The only major argument I have with patents from a nomenclatural viewpoint occurs when a new taxon is proposed. Sometimes the only cited "authority" for the name is a business concern or research organization. However, the authority problem is in no greater question in the patent literature than it is in the scientific literature. As a result of Rule 11, many newly proposed names for organisms in the order Actinomycetales, as well as for other organisms, are "in limbo" nomenclaturally. Such names are used continually by the scientific and nonscientific community and serve a useful purpose despite their nonvalidity. But there are more problems involved. For one 
reason or another, the person or persons responsible for coining the name cannot or will not validate the name in a scientific publication. Consequently, there is a real bar to progress in taxonomy, dependent, in final analysis, upon scientifically acceptable names.

Had Rule 11 not been enacted, the nomenclature specialist would simply ferret out the first patent or other publication concerned with the new name and resolve the authority problem. Now he not only has to do this task, but also for proper documentation he should record all patents and other material issued prior to the first valid publication of the name. Also Rule 11 has brought about the embarrassing situation for some taxonomists who use the nonvalid names in scientific publications and then find themselves set down (incorrectly) as authorities for the name even though they had nothing to do with isolation of the organism in question, with its characterization (other than providing additional information obtained in a taxonomic study), or with coinage of the name. Accordingly, I suggest some consideration be given to resolving the problem of names in patents with the idea of amending Rule 11 so that these names can be properly removed from limbo.

At the start of my work, I was faced with the problem of selecting only validly published and legitimate names requiring, of course, the evaluation of published material in terms of the Code. Some nomenclatural evaluations were available in Index Bergeyana (8) and two of the supplements thereto $(15,43)$. I was not in complete agreement with some of the conclusions drawn therein. My master list still contained an exceedingly long list of names from the scientific, quasiscientific, and patent literature. Also, I was quite aware of the Actinomyces-Streptomyces problem.

Thus, the first problem was to seek out the original source of the name and to track through subsequent references to first valid publication. It was no easy task to compile and evaluate such lists of references, particularly when many were in foreign languages and in patents. An immediate question arose. "What constitutes an effective publication?" Because Rule 11 of the Code singles out patents in particular, one might raise questions about other organs of communication, e.g., abstracts, theses, microfilms of theses, and annual reports of scientific research organizations. It may be that we need a list of acceptable publications. In these days of widespread dissemination of virtually all kinds of printed matter, with or without charge to the recipient, only time and effort, plus occasionally some money, are required for the general public or microbiological institutions to secure the material in hand. From a list of the kinds of printed matter, a decision could be made as to which of these constitute effective publication: mimeographed, multilithed, or reproduced material; newspapers; descriptive brochures; catalogues; abstracts of papers and patents; theses; microfilm copies of printed matter; dictionaries; encyclopedias; books; monographs; patents; patent applications; annual reports of scientific and industrial organizations; advertisements; advertising brochures; nonscientific, scientific, and trade magazines and journals; and isolated publications from business and research organizations among others. One solution, of course, would be for scientists to ensure that the first publication of a new name be documented in print in an acceptable scientific journal. Listing an evaluation of the name Actinomyces olivoviridis is an example of the kind of problem now encountered.

Actinomyces olivoviridis n. sp. (sic) Krasil'nikov, Kuchaeva and Skryabin 1959. (Supplement to Program for Symposium on Antibiotics, 18-23 May 1959, Prague, Czechoslovakia; Multilithed abstract carrying no pagination). Not Val. Pub.

Actinomyces olivoviridis n. sp. (sic) Kutchaeyeva, Krasil'nikov and Skriabin 1960. (Proceedings of the Symposium on Antibiotics, 18-23 May 1959, Prague, Czechoslovakia: 58-59). Not Val. Pub. Inadequate description.

Actinomyces olivovirilis (sic) n. sp. (sic) Kuchaeva, Krasil'nikov, Skryabin and Taptykova, In Rautenshtein (ed.) 1960. (Tr. Inst. Mikrobiol., Akad. Nauk, SSSR 8:248). A lapsus calami.

Actinomyces olivoviridis n. $\mathrm{sp}$. (sic) Kuchaeva, Krasil'nikov, Skryabin and Taptykova In Rautenshtein (ed.) 1960. (Tr. Inst. Mikrobiol., Akad. Nauk, SSSR 8:251; English translation 1966, 249). Val. Pub., Leg.

Aside from the question of validity of publication of the name, another problem of real concern was determination of the proper authorities for names. One might imply from rules $14 \mathrm{a}$ and $14 \mathrm{~b}$ of the Code that, for valid publication of names of species and subspecies, there is no requirement for citation of the author and date of publication of the name. Rule 15a states that it is necessary to cite the author who first published the name in question in order for the indication of the name of a taxon to be accurate and complete. Possibly as a consequence of the separation of Rules 14 
and 15, and possibly because tackling the authority problem is just too much for the average microbiologist, particular combinations of generic names and specific or subspecific epithets are accompanied by many different citations of authority in the literature. The job of determining the proper authority thus becomes one of considerable magnitude. For example, Table 2 lists some "complete" names containing the epithet "albus" I have found in the literature.

The same situation can be found with other common specific epithets used in the names of organisms placed in the Order Actinomycetales, e.g., "aureus," "griseus," "roseus," and "viridis."

Obviously there is much confusing information in the literature with respect to authorities for names. When only one person is listed as the author of a publication there is no problem, but in these days of the research team, single authorship is an exception rather than the rule. When more than one author is listed, many questions arise. In some papers five or more authors are listed, for example:

Actinomyces grisinus Krasil'nikov, Belozersky, Rautenstein, Korenyako, Nikitina, Sokolova and Uryson 1957.

Streptomyces cinnamoneus Benedict, Dvonch, Shotwell, Pridham and Lindenfelser 1952.

Rule $15 \mathrm{a}$ of the Code states that these could be reduced to the senior author followed by the abbreviation et al. Obviously, not all the authors worked on characterization of the organism or in coining its name. The question

TABLE 2. Authorities cited for Actinomyces albus as taken from various literature sources

A. albus Gasperini, 1894.

A. albus (Rossi Doria) Gasperini, 1894.

A. albus (Rossi Doria) Krassil'nikov, 1949.

A. albus Krainsky, 1914.

A. albus Waksman et Curtis, 1916.

A. albus Lehmann et Neumann.

A. albus Gasperini, 1890.

A. albus (Krainsky) Waksman et Curtis.

A. albus (Krainsky, A., 1914) emend. Waksman S.A. et R. E. Curtis, 1916.

A. albus (Rossi-Doria, 1891) Krainsky, A., 1914.

A. albus (Krainsky) Waksman et Curtis, 1919.

A. albus Tarozzi, 1909.

A. albus Waksman et Curtis, 1916 vide etiam Waksman, 1919.

A. albus Krasil'nikov, 1941. then might be raised with respect to a definition for the term "authority." The person who first coins a name might be an attorney, a chemist, a Latin or Greek scholar, or the microbiologist who isolated and characterized the organism. "Published" may be the key word in Rule $15 \mathrm{a}$, but it needs clarification.

Another example in point is Streptomyces hydrogenans. So far as I have determined, the name was first proposed in a German "Ausgelegeschrift" by Lindner et al. (26) and hence is not validly published. A valid publication of the name is cited in Index Bergeyana with the authorities Lindner et al. (25). However, a notation in this paper states that $\mathrm{K}$. Wallhäusser is credited with the investigation and characterization of the taxon. In the old days of bacteriology, lone scientists often isolated organisms, characterized them, conducted taxonomic evaluations, and coined the names. Now, with the teamwork approach to many problems in microbiology, each of these operations may be carried out by different individuals. We need a precise definition of what constitutes an authority for a name. The problem is further complicated by the practice on the part of some microbiologists of using personal names as strain designations. These have been construed by some as the names of the authors of the name of the species or subspecies. One major collection used this device for many years.

Microbiologists should exert all possible pressure to see that the proper authority, once we have established exactly what that is, is connected with the name of a new taxon somewhere in the body of the printed matter. Insertion of a simple statement such as, "The authors decided to assign this strain to a new species $S$. kanamyceticus $\mathrm{n}$. $\mathrm{sp}$. Okami et Umezawa." would solve the problem. This form was used by the Japanese workers in this particular example (41). A more formal statement might have been: "We propose that the new taxon be named Streptomyces kanamyceticus Okami and Umezawa." Comparable statements would allow continuity in authority designation from the first printed material distributed. They also are proper for inclusion in patents and published patent applications, provided no juridicial barriers exist, though these sources are nonvalid publications now. In my view, the problem of authorities for names requires reexamination with reference to the Code.

Another question related to valid publication concerns Rule $12 \mathrm{a}$, wherein it is stated that a name to be validly published must be accompanied by a description of the taxon or 
by a reference to a previously and effectively published description of it. The question of whether the organism is described sufficiently so that the name applied to the organism is not a nomen dubium (a name whose application is uncertain) is left to the individual. Often descriptions leave much to be desired insofar as adequacy is concerned, and, with the kinds of organisms with which we are dealing, today's adequate description may be inadequate 5 years hence. Examples of names accompanied by inadequate descriptions are:

Streptomyces floridae-a raspberry to violetcolored actinomycete; produces viomycin (3).

Streptomyces colombiensis-produces vita$\min \mathrm{B}_{12}$ (31). (40).

Streptomyces natalensis-produces pimaricin

Actinomyces diastatochromogenes-cultural and physiological characteristics only (22).

Streptomyces subtropicus-produces albomycin complex (6). No such name in publication.

Streptomyces toyocaensis-produces toyocamycin (28).

Streptomyces jamaicensis-produces monamycin (14).

Each of these names is evaluated as being validly published in Index Bergeyana. None had an adequate description in my opinion. I submit that Rule 12a of the Code might contain the statement, "...must be accompanied by an adequate description of the taxon or by a reference to a previously and effectively published adequate description of it." Otherwise, the only requirement is for effective publication, i.e., the determination of whether printed matter containing the name represents an acceptable publication, i.e., whether it is a scientific publication.

Requiring an adequate description, of course, raises the question, "How does one determine what constitutes an adequate description of a taxon, particularly when the taxonomy is continually subject to the addition of new criteria?" It would seem that the various international subcommittees on taxonomy could answer this question. For example, our International Subcommittee on Taxonomy of Actinomycetes already has recommended certain minimal criteria for use in descriptions appearing in patents $(11,12)$. These same minimal criteria could be recommended for characterization and description of any organism in the order Actinomycetales in any printed matter and could be revised at periodic intervals. I therefore suggest that some con- sideration be given to this adequacy requirement in establishing valid publication. As a matter of fact, a contemporary taxonomist could reevaluate the entire Order Actinomycetales and eliminate many older names based on adequacy of description alone.

A minor problem, but one for which some note should be taken, concerns the final entry in the complete name for a taxon, i.e., the page on which the proposal for the new name appears. In some publications, the new name is referred to several times in various parts of the manuscript. For example $A$. rectiviolaceus Artamonova in Krasil'nikov 1965 is specified as "n. sp." in the title of the paper (2); in the introduction on page 234; in the title for an illustration on page 235 ; in a table on page 236 ; in a section of physiological and biochemical characteristics on page 237 ; in a table of carbon utilization results on page 238; on pages $239-241,245-247$, and 249 ; and finally, in boldface type heading a general summary of the characteristics on page 250 . Zvirbulis and Hatt cited page 250 in their evaluation of the name (43). However, what is the rule here? Personally, I believe the pagination should refer to the first page on which the name occurs, regardless of whether it is in the title or of how close it is to a description. In the paper by Artamonova (2), the description is scattered throughout the pages and is summarized on page 250 , whereas the implied proposal of a new taxon lies in the title of the article.

Another major problem encountered during my work lay in documenting the designation of the type strain of a given taxon. In the great majority of published descriptions of streptomycetes and streptoverticillia, there is no precise designation of a type strain. Despite some objections to the type-strain concept, it appears to be the only practical approach to take when confronted with a multispecies genus such as Streptomyces. It really does not matter what position a type strain may occupy in the species sphere, and certainly one could never hope to cover the entire range of variation exhibited by a particular taxon. Thus, from a systematic viewpoint, there is need for a bench mark of some kind, i.e., the type strain. Some descriptions obviously were based on study of a single strain. These can be assumed to be the type strain (single isolate), Rule 9d (2). Unfortunately, sometimes the type strain was not assigned a strain designation; cultures distributed as belonging to the type strain bore designations different from the published designation for the type strain; different individuals 
have received different strains on request for the type strain; and so on. All sorts of variations of this theme were encountered, and the search for the correct original strain designation often was tedious. Also, where no strain of several listed or characterized is designated as the type strain in the original publication, anyone may designate a type strain for that taxon, but it has to be one of the strains on which the original description of the species or subspecies was based and presumably would be listed and/or characterized in the original publication. Any other strains are simply reference strains or potential neotype strains. This lack of formal designation of the type strain was a major obstacle in getting at the facts. Interestingly, I had to refer to some papers which were not effectively published in ferreting out the original strain designations for some streptomycetes.

Another point of concern has been the misconception that the authority also refers to the strain designation, i.e., that $S$. griseus (Krainsky) Waksman and Henrici, with no strain designation as listed in culture collection catalogues or other publications, refers in fact to progeny of Krainsky's original strain isolated ca. 1914. This concept is not true. Progeny of most, if not all, of Krainsky's original isolates no longer exist. Names accompanied by their proper authority citation also should be accompanied by the correct strain designation(s) in taxonomic works. It is beyond my comprehension why a systematist cannot, on first isolation and purification of members of a particular taxon, assign to the members strain designations and, moreover, select one of a series of similar strains as the type strain for the new taxon he intends to name. The particular strain may represent the central point or either end of a range of variation. This problem would have to be worked out later and actually represents one part of a lumping process or population study.

Beyond the selection of the type strain and its designation, its documentation could be set forth in patents or other publications by insertion in the text of a simple statement such as, "The type strain of this taxon is (2- to 5-letter abbreviation for research organization or culture collection)-(1- to 6-number designation)," e.g., NRRL B-1699. Accordingly, I suggest modification of Rule 8 a (1) to include a statement such as, "It may be designated in any manner, preferably by two to five letters indicating the collection or laboratory housing the organism, followed by one to six numerals indicating the particular strain number. Use of the names of individuals or localtities as strain designations may result in confusion with the names of authorities for the taxon in question and are not recommended." Thus, NRRL B-150, NIHJ-236, ATCC 17560, CBS 123.39, and INMI 18-18 are appropriate designations that adequately pinpoint particular strains and can serve effectively in communication either with or without the formal name of the organism. This method for strain designation has been used by the major culture collections for many years.

Actinomycetologists should pay particular attention to the selection of the type strain and to its appropriate designation in the initial abstracts, papers, or patents wherein the name is proposed. There is no question in my mind that with the organisms with which we are concerned, there is need for a type strain appropriately designated, regardless of its particular taxonomic position. All other strains represent reference strains and potential neotypes should the type strain be lost.

Another major problem I encountered concerns derivation or coining of specific and subspecific epithets. Frequently, allusions are made in the text as to the derivation of a particular name. In other instances, for example, "kanamyceticus," there is no indication. The seventh edition of Bergey's Manual of Determinative Bacteriology (7) neatly presents this information, i.e., the syllabication of the epithet followed by its etymology. For example, for Streptomyces violaceoniger (Waksman and Curtis, 1916) Waksman and Henrici 1948, 947 one finds: vi.o.la.ce.o'ni.ger. L. adj. violaceus violet; L. adj. niger black; M.L. adj. violaceoniger violet-black.

I attempted to work out many of the names included in my exercise for which no syllabications or etymologies were given. It took about 30 min per name using publications such as Collin's Latin Gem Dictionary (21), Marchant and Charles' revision of Cassell's Latin Dictionary (no date), Jaeger's $A$ Source-Book of Biological Names and Terms (18), Cash's $A$ Mycological English-Latin Glossary (9), and Webster's New Unabridged Dictionary (42), as well as many other foreign language dictionaries and sources of information. There are, of course, later editions of some of the references cited. An unabridged Latin dictionary should also be used for such work.

One complication occurred because Rule 6 of the Code states that a specific epithet may be taken from any source whatever and may 
even be composed arbitrarily. As a result, I still have some names that defy solution. If names are composed arbitrarily, such a notation should be made and some explanation of the reason for the epithet should be given.

There now is a formal list of names in Index Bergeyana and its several supplements, and I recommend that the epithets listed therein not be used in coining names of new taxa in the Actinomycetales. I encountered several examples where the same name was proposed for different taxa. Accordingly, I suggest that an "absolute epithet priority rule" for the order Actinomycetales be considered and that evaluation of the nomenclature and taxonomy of a particular species or subspecies in the order Actinomycetales Buchanan 1917 should be based on the earliest history associated with a specific or subspecific epithet. This action would broaden Rules 6 and 7. For example, as outlined in Pridham et al. (32), the first use of the epithet "aureus," or its feminine and neuter forms "aurea" and "aureum" in referring to an actinomycete, was by Johan-Olsen (19). Subsequently other investigators, apparently unaware of his proposal, coined presumably new names with one or the other of the epithets cited. These probably referred to entirely different organisms. Application of an "absolute priority" concept would help to clear the air with respect to the taxonomy of some of the older "species." There should be only one "aureus," "aureum," or "aurea" and that with the basionym Actinomyces aureus Johan-Olsen 1893, 79. Furthermore, the taxonomy of that taxon should be based on the characteristics cited in his publication. As pointed out earlier (32), study of the reported characteristics for strains with the specific epithets "aureus," "aurea," or "aureum" assigned in the literature on Actinomycetales, especially in connection with the genera Actinomyces, Streptothrix, Nocardia, Discomyces, and Oospora (and I might add Streptomyces), suggests that the species (Actinomyces aureus, Streptothrix aurea, Nocardia aurea, Oospora aurea, and Streptomyces aureus) are taxonomically questionable and should not be recognized. Any names other than Actinomyces aureus JohanOlsen 1893, 79 which contain the specific epithet aureus or its orthographic variants simply represent misidentifications based on lack of knowledge of the history associated with the epithets "aureus," "aurea," or "aureum" as they relate to the order Actinomycetales. Many names such as these already have been rejected by taxonomists through omission. Others have been rejected formally in
Index Bergeyana. Any strains (if they are available) carrying such questionable names should be considered unnamed until taxonomists either rename them more appropriately or assign new, correct names to them. Table 3 lists the epithet "citreus" and its feminine and neuter forms as now represented in the order Actinomycetales. In my opinion these deserve the same fate as "aureus."

Further, I believe the practice of correcting the original orthography of an epithet when the epithet is misspelled leads to even greater confusion despite good intentions. There are examples now of accepted names where a slight difference in spelling exists for two completely different taxa-Streptomyces canus (sic) Heinemann, Kaplan, Muir and Hooper, 1953, 1239 and Actinomyces canis (sic) Baudet 1934 , 301. Canus is the Latin adjective meaning white or gray; canis is the Latin noun meaning dog or bitch. On the other hand, there are examples of epithets differently spelled that might be construed as representing different taxa but are referring to one and the same taxon and, in fact, to the same strain; e.g., Streptomyces canescens (17) Waksman 1957, 968, and Streptomyces canescus Hickey, Corum, Hidy, Cohen, Nager and Kropp 1952, 473. I, myself, unwittingly perpetrated similar confusion in connection with the nomenclature of the cinnamycin-producing organism. In attempting to

TABLE 3. Names of Actinomycetales that contain "citreus," "citrea," or "citreum" as specific or subspecific epithets

\begin{tabular}{|c|c|}
\hline Name & $\begin{array}{l}\text { Date of } \\
\text { proposal }\end{array}$ \\
\hline Actinomyces citreus & 1894,1914 \\
\hline Streptothrix citrea. & 1896 \\
\hline Nocardia citrea ...... & 1916,1948 \\
\hline Proactinomyces citreus . . . . . . . . & 1938 \\
\hline Actinomyces flavus subsp. citreus . . . & 1941 \\
\hline Mycobacterium citreum ........ & 1941 \\
\hline M. citreum subsp. flavoviride . . . . & 1941 \\
\hline M. citreum subsp. liquefaciens .... & 1941 \\
\hline M. citreum subsp. paulotrophum ... & 1941 \\
\hline M. citreum subsp. putrificum . . . . & 1941 \\
\hline Streptomyces citreus . . . . . . . . . . & 1948 \\
\hline $\begin{array}{l}\text { Proactinomyces citreus subsp. } \\
\quad \text { marinae } \ldots \ldots \ldots \ldots \ldots \ldots \ldots\end{array}$ & 1949 \\
\hline M. citreum subsp. mucosum . . . . & 1949 \\
\hline M. citreum subsp. lacticum . . . . . & 1949 \\
\hline Promicromonospora citrea . . . . . . & 1961 \\
\hline P. citrea niger $\ldots \ldots \ldots \ldots \ldots \ldots$ & 1961 \\
\hline Actinomyces candidus subsp. citreus . & 1964 \\
\hline
\end{tabular}


correct what I believed to be an error in spelling of the epithet, I changed the name from Streptomyces cinnamoneus (sic) Benedict, Dvonch, Shotwell, Pridham and Lindenfelser 1952, 591, to Streptomyces cinnamomeus (33). It would have been better had I left the original spelling of the epithet intact since now there exist about a half dozen different names for this taxon.

I have presented this material to illustrate the problems that arise when an average microbiologist attempts to coordinate taxonomic studies with nomenclature. Such coordination should be the obligation of any systematist. However, it is not so easy as it may seem. Some of the problems I have discussed can be handled by following a simple format (30) in proposing a new name or new combination as illustrated in the following example concerning Actinomyces albohelvatus.

For a new name. "We propose that this new taxon be named Actinomyces albohelvatus Krasil'nikov, Korenyako and Nikitina.

The type strain of Actinomyces albohelvatus is INMI 1349 by original designation.

Etymology: al.bo.hel.va'tus L. adj. albus white; L. adj. helvatus honey-yellow; M.L. adj. albohelvatus light honey-yellow, referring to the color of the vegetative mycelium of the organism."

For a new combination. "Streptomyces albohelvatus [Krasil'nikov, Korenyako and Nikitina in Krasil'nikov (ed.), 1965] comb. nov.

Type strain: (none by original designation) is INMI 1349 (by subsequent designation by Krasil'nikov in Shirling and Gottlieb (38) for the International Streptomyces Project).

Synonymy: Actinomyces albohelvatus Krasil'nikov, Korenyako and Nikitina in Krasil'nikov (ed.) 1965, 224.

Etymology: al.bo.hel.va'tus L. adj. albus white; L. adj. helvatus honey-yellow; M.L. adj. albohelvatus light honey-yellow, referring to the color of the vegetative mycelium of the organism."

If our present approach to taxonomy and nomenclature of the Actinomycetales is to continue, the simple formats outlined above would do much to lessen the labors of whoever might be involved in collating information on the large numbers of new names and new combinations that are bound to appear.

I hope that my remarks might bring about some dialogue and alert systematists to the consequences of their handling of nomenclature in any kind of printed matter. As it now stands, I can see why some taxonomists might be tempted simply to ignore the Code. Hopefully they will not. Simplification of the Code might help, lest we become so embroiled in promulgation of additional new rules and regulations as to exert a stifling effect on progress in the combined area of systematics-nomenclature. I purposely have selected examples to illustrate the international aspects of the problems.

\section{LITERATURE CITED}

1. Anonymous. 1963. News and Notes. Action of the Subcommittee on Taxonomy of the Actinomycetes. Int. Bull. Bacteriol. Nomencl. Taxon. 13(3): 175 .

2. Artamonova, O. E. 1965. New species of violet colored actinomycetes Actinomyces rectiviolaceus n. sp., p. 234-251. In N. A. Krasil'nikov (ed.), Biology of individual groups of Actinomycetes. (In Russian) Moscow.

3. Bartz, Q. R., J. Ehrlich, J. D. Mold, M. A. Penner, and R. M. Smith. 1951. Viomycin, a new tuberculostatic antibiotic. Amer. Rev. Tubercl. 63(1):4-6.

4. Baudet, E. 1934. Actinomycose du chien. Ann. Parasit. Hum. Comp. 12:296-308.

5. Benedict, R. G., W. Dvonch, O. L. Shotwell, T. G. Pridham, and L. A. Lindenfelser. 1952. Cinnamycin, an antibiotic from Streptomyces cinnamoneus nov. sp. Antibiot. Chemother. 2:591-594.

6. Brazhnikova, M. G., N. N. Lomakina, and L. I. Murav'eva. 1954. Albomycin, its characteristics and chemical nature. Dokl. Akad. Nauk. SSSR 99:827-830.

7. Breed, R. S., E. G. D. Murray, and N. R. Smith. 1957. Bergey's manual of determinative bacteriology, 7 th ed. The Williams \& Wilkins Co., Baltimore.

8. Buchanan, R. E., J. G. Holt, and E. F. Lessel, Jr. (ed.). 1966. Index Bergeyana. An annotated alphabetic listing of names of the taxa of bacteria. The Williams \& Wilkins Co., Baltimore.

9. Cash, E. K. 1965. Mycological memoir no. 1. A mycological English-Latin glossary. Hafner Publishing Co., New York.

10. Cranberg, L. 1968. Law-scientific and juridicial. Amer. Sci. 56(3):244-253.

11. Gottlieb, D. 1963. Recommendations for descriptions of some Actinomycetales appearing in patent applications. Int. Bull. Bacteriol. Nomencl. Taxon. 13(3): 169-170.

12. Gottlieb, D. 1964. Recommendations for descriptions of some Actinomycetales appearing in patent applications. Amer. Soc. Microbiol. News $30(2): 13-14$.

13. Gould, S. W. 1954. Permanent numbers to supplement the binomial system of nomenclature. Amer. Sci. 42:269-274.

14. Hassall, C. H., and K. E. Magnus, 1959. Monamycin: a new antibiotic. Nature (London) 184:1223-1224.

15. Hatt, H. D., and E. Zvirbulis. 1967. Status of names of bacterial taxa not evaluated in Index Bergeyana (1966). 1. Names published circa 
1950-1967 exclusive of the genus Salmonella. Int. J. Syst. Bacteriol. 17(2):171-225.

16. Heinemann, B., M. A. Kaplan, R. D. Muir, and I. R. Hooper. 1953. Amphomycin, a new antibiotic. Antibiot. Chemother. 3:1239-1242.

17. Hickey, R. J., C. J. Corum, P. H. Hidy, I. R. Cohen, U. F. B. Nager, and E. Kropp. 1952. Ascosin, an antifungal antibiotic produced by a streptomycete. Antibiot. Chemother. $2: 472-483$.

18. Jaeger, E. C. 1950. A source-book of biological names and terms, 287 p. 2nd ed. Charles C Thomas, Publisher, Springfield, Ill.

19. Johan-Olsen, O. 1893. One Soppaa levende Jordbund Kristiania, p. 91-96. Inaug. Diss. Christiania Univ., Norway.

20. Judicial Commission. The Editorial Board of the Judicial Commission of the International Committee on Nomenclature of Bacteria. 1966. International Code of Nomenclature of Bacteria. Int. J. Syst. Bacteriol. 16(4):459-490.

21. Kidd, D. A. 1962 . Collins's Latin gem dictionary, 674 p. Collins Clear Type Press, London.

22. Krainsky, A. 1914. Die Aktinomyceten und ihren Bedeutung in der Natur. Zentralbl. Bakteriol. Parasitenk. II Abt. 41:649-688.

23. Leimgruber, W., V. Stefanović, F. Schenker, A. Karr, and J. Berger. 1965. Isolation and characterization of anthramycin, a new antitumor antibiotic. J. Amer. Chem. Soc. 87:5791-5793.

24. Lessel, E. F. 1968. On proposing new names and combinations. Int. J. Syst. Bacteriol. $18(1): 49-50$.

25. Lindner, F., R. Junk, G. Nesemann, and J. Schmidt-Thomé. 1958. Gewinnung von 20 $\beta$-hydroxysteroiden aus $17 \alpha-21$ Dihydroxy-20ketosteroiden mit Streptomyces hydrogenans. Hoppe-Seyler's Z. Physiol. Chem. 313:117-123.

26. Lindner, F., J. Schmidt-Thomé, R. Junk, and G. Nesemann. 1957. Verfahren zur Herstellung von 20-Oxysteroiden. Deutsches Auslegeschrift $1,016,263$, September 26.

27. Marchant, J. R. V., and J. F. Charles. (no date). Cassell's Latin Dictionary, Funk \& Wagnalls Co., New York.

28. Nishimura, H., K. Katagiri, K. Sato, M. Mayama, and N. Shimaoka. 1956. Toyocamycin, a new anti-candida antibiotic. J. Antibiot. (Tokyo), Ser. A, 9:60-62.

29. Pridham, T. G. 1959. Retrospections on streptomycete taxonomy. Rev. Latin Amer. Microbiol. Suppl. 3:1-25.

30. Pridham, T. G. 1970. New names and new combinations in the order Actinomycetales Buchanan 1917. U.S. Department of Agriculture Technical Bulletin 1424 .

31. Pridham, T. G., C. W. Hesseltine, and R. G. Benedict. 1958. A guide for the classification of streptomycetes according to selected groups.
Placement of strains in morphological sections. Appl. Microbiol. 6:52-79.

32. Pridham, T. G., A. J. Lyons, Jr., and H. L. Seckinger. 1965. Comparison of some dried holotype and neotype specimens of streptomycetes with their living counterparts. Int. Bull. Bacteriol. Nomencl. Taxon. 15(4):191-237.

33. Pridham, T. G., O. L. Shotwell, F. H. Stodola, L. A. Lindenfelser, R. G. Benedict, and R. W. Jackson. 1956. Antibiotics against plant disease. II. Effective agents produced by Streptomyces cinnamomeus forma azacoluta f. nov. Phytopathology 46:575-581.

34. Savory, T. 1962. Naming the living world. An introduction to the principles of biological nomenclature. The English Universities Press, Ltd., London.

35. Shirling, E. B., and D. Gottlieb. 1966. Methods for characterization of Streptomyces species. Int. J. Syst. Bacteriol. 16(3):313-340.

36. Shirling, E. B., and D. Gottlieb. 1968a. Cooperative description of type cultures of Streptomyces. II. Species descriptions from first study. Int. J. Syst. Bacteriol. 18(2):69-189.

37. Shirling, E. B., and D. Gottlieb. 1968b. Cooperative description of type cultures of Streptomyces. III. Additional species descriptions from first and second studies. Int. J. Syst. Bacteriol. 18(4):279-392.

38. Shirling, E. B., and D. Gottlieb. 1969. Cooperative description of type cultures of Streptomyces. IV. Species descriptions from the second, third and fourth studies. Int. J. Syst. Bacteriol. 19(4):391-512.

39. Siu, R. G. H., and E. T. Reese. 1955. Proposal for a system of biological nomenclature, with special reference to microorganisms. Farlowia 4(4):399-407.

40. Struyk, A. P., I. Hoette, G. Drost, J. M. Waisvisz, T. van Eek, and J. C. Hoogerheide. 1958. Pimaricin, a new antifungal antibiotic, p. 878-885. Antibiot. Ann. 1957-1958. Medical Encyclopedia, Inc., New York.

41. Umezawa, H., M. Ueda, K. Maeda, K. Yagishita, S. Kondo, Y. Okami, R. Utahara, Y. Ösato, K. Nitta, and T. Takeuchi. 1957. Production and isolation of a new antibiotic, kanamycin. $J$. Antibiot. (Tokyo), Ser. A 10(5):181-188.

42. Webster's New International Dictionary of the English Language. 1945. 2nd ed., unabridged. G. \& C. Merriam Co., Springfield, Mass.

43. Zvirbulis, E., and H. D. Hatt. 1969a. Status of names of bacterial taxa not evaluated in Index Bergeyana (1966). Addendum II. Acetobacter to Butyrivibrio. Int. J. Syst. Bacteriol. 19(1):57-115.

44. Zvirbulis, E., and H. D. Hatt. 1969b. Status of names of bacterial taxa not evaluated in Index Bergeyana (1966). Addendum III. Achromobacter to Lactobacterium. Int. J. Syst. Bacteriol. 19(3):309-370. 